\title{
Utilization of Aldose by Cock's Spermatozoa
}

\author{
Hisayoshi Nishiyama and Toru Fujishima \\ (Department of Zootechnical Science, Faculty of Agriculture, Kagoshima University, \\ Kagoshima, Japan)
}

(Received for Publication on December 3, 1960)

The ejaculate of the cock is a mixture of semen ejected from the vas deferens and accessory reproductive fluid, or so-called transparent fluid ${ }^{1 / 21}$. The transparent fluid contains aldose (presumably blood glucose) at the same level as blood serum. Then aldose is present most frequently in the ejaculate ${ }^{2)}$.

The present experiment was performed to ascertain whether cock's spermatozoa utilized the aldose contained in the ejaculated semen and to investigate the relationship between the rate of aldose utilization and sperm motility.

\section{Materials and Methods}

Ejaculated semen was collected with a semen collector ${ }^{21}$ from 6 S. C. White Leghorn cocks. Just after ejaculation, one drop of the ejaculated semen was spotted on filter paper. Spotting was repeated several times at 10 -minute intervals for one hour or more. The detection and scoring of aldose in the chromatograph was done by the method described by Nishiyama and Fulshima ${ }^{23}$.

To ascertain the influence of sperm activity and sperm density on the utilization of aldose by spermatozoa, the following two experiments were performed with the vas-deferens semen, transparent fluid, and the modifled Ringer-Locke solution which contained 0.2 per cent glucose. Vas-deferens semen was obtained from $10 \mathrm{~S}$. C. White Leghorn cocks by squeezing the vas deferens at autopsy. The transparent fluid was collected from 4 vasectomized cocks ${ }^{2)}$ with a semen collector and stored in frozen state.

To ascertain the influence of sperm activity, the vas-deferens semen was diluted with an equal amount of the transparent fluid or the modified Ringer-Locke solution. The diluted semen was divided equally into 2 test tubes. One of the tubes was incubated at $30^{\circ} \mathrm{C}$ and the other cooled at about $0^{\circ} \mathrm{C}$, using thermos bottles which contained either warm water at $30^{\circ} \mathrm{C}$ or cracked ice. The diluted semen in the incubated tube was spotted at 10 -minute intervals and that in the cooled tube at one-day intervals to determine aldose. Sperm activity was evaluated by the hanging drop method and scored on a basis of 0 to 5 in all semen samples.

To ascertain the influence of sperm density, the vas-deferens semen was divided in to 3 portions, which were diluted with the modified Ringer-Locke solution containing 0.2 per cent glucose, at the ratio of $1: 1,1: 2$, and $1: 5$, respectively. The diluted semen was incubated at $30^{\circ} \mathrm{C}$ and the degree of aldose reaction was determined at 10 -minute intervals. The density of the semen samples was determined by the routine methods.

\section{Results and Discussion}

1. Decrease in aldose score of ejaculate with lapse of time. 
The aldose score of ejaculate just after ejaculation was quite variable, ranging from 1 to 3. It was zero in a few samples. There was a tendency that the higher semen density, the lower aldose score an ejaculate gave, as mentioned in the previous paper ${ }^{2}$.

When the ejaculated semen was allowed to stand at room temperature between 10 and $20^{\circ} \mathrm{C}$, its aldose score decreased rapidly with the lapse of time (Figs. 1 and 2). The time

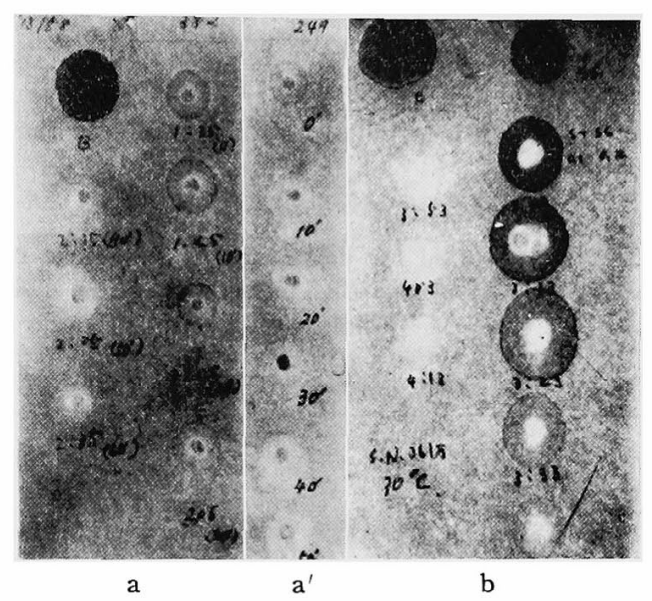

Fig. 1. Aldose test on semen.

a and $\mathbf{a}^{\prime}$ : Ejaculated semer.

a, Chromatograph showed Positive reaction just after collection $\left(\mathrm{o}^{\prime}\right)$ with a score of 1.5 , and became negative after 40 minutes

$a^{\prime}$, Positive reaction with a score of 1 , became negative after 10 minutes. $B=$ blood plasma

b, The vas-deferens semen was diluted with transparent fluid at the rate of $1: 1$ and incubated at $30^{\circ} \mathrm{C}$. Aldose test became negative after 50 minutes. $\quad \mathrm{B}=$ blood plasma; $\mathrm{SS}=$ transparent fluid.

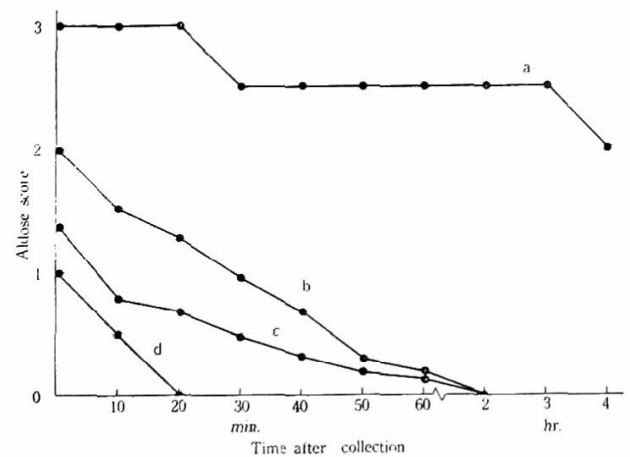

Fig. 2. Decrease in score of aldose test at different density (number of sperms"per cubic millimeter) of ejaculate.

a: less than 1 million, b: 1-3 millions, c: $3-5$ millions, and"d: more than 5 millions. Values in $b$ and $c$ are average of 6 and 8 samples, respectively. Values in a and $d$ were obtained from only one sample each. 


\section{Utilization of aldose by sperm}

required for the disappearance of aldose seemed to be related to the density of the semen sample involved. There was a general tendency that the higher the density of a sample, the more rapid the disappearance of aldose from it (Table 1). For example, of 9 samples of dense semen, containing 3 million or more spermatozoa per cubic millimeter, 5 samples, or 56 per cent, gave negative results in aldose test within 30 minutes after collection and about 90 per cent of the samples in an hour. Conversely, of 7 samples of dilute semen containing less than 3 million spermatozoa, only one gave negative results 30 minutes after collection and 57 per cent of the samples an hour or more. This relationship was clearly shown in 2 samples, one very dense (more than 5 million spermatozoa) and the other very dilute (less than 1 million).

Table 1. Time required for disappearance of aldose reaction

\begin{tabular}{|c|c|c|c|c|c|c|c|c|c|c|}
\hline \multirow{2}{*}{$\begin{array}{c}\text { No. of spermatozoa } \\
\text { million } / \mathrm{mm}^{8}\end{array}$} & \multirow{2}{*}{$\begin{array}{r}\text { No. of } \\
\text { samples }\end{array}$} & \multicolumn{9}{|c|}{ Time in min. and hr. after collection } \\
\hline & & $10 \mathrm{~m}$ & $20 \mathrm{~m}$ & $30 \mathrm{~m}$ & $40 \mathrm{~m}$ & $50 \mathrm{~m}$ & $60 \mathrm{~m}$ & $1.5 \mathrm{~h}$ & $2 \mathrm{~h}$ & $\begin{array}{c}\text { More than } \\
4 \mathrm{~h}\end{array}$ \\
\hline $\begin{array}{c}\text { Less than } 1 \\
\begin{array}{c}1-2 \\
2-3 \\
3-4 \\
4-5\end{array} \\
\text { More than } 5\end{array}$ & $\begin{array}{l}1 \\
3 \\
3 \\
6 \\
2 \\
1\end{array}$ & $\begin{array}{l}1 \\
1\end{array}$ & 1 & 2 & $\begin{array}{l}1 \\
1 \\
1\end{array}$ & 1 & 1 & 1 & 1 & 1 \\
\hline
\end{tabular}

There was also a tendency that the rate of decrease of aldose score with the lapse of time was related to the temperature at which the semen sample had been stored, i.e., to the activity of spermatozoa, although this was not indicated in the table or the flgure.

2. Utilization of the aldose contained in the transparent fluid and in the modified RingerLocke solution by cock's spermatozoa.

To ascertain whether cock spermatozoa utilize the aldose contained in the transparent fluid and to investigate more accurately the relationship between the rate of aldose utilization and sperm motility, the vas-deferens semen was added to the pure transparent fluid or to the modified Ringer-Locke solution and the rate of disappearance of aldose in the diluted semen was determined.

The vas-deferens semen which had been diluted with the transparent fluid at the rate of $1: 1$ was scored 1.5 or 2 in the aldose test just after dilution, since the vas-deferens semen lacked aldose and the transparent fluid gave a positive test, with a score of 3 , as described in the previous paper ${ }^{2)}$. The aldose-test scores of these diluted semen samples decreased rapidly when the semen had been incubated at $30^{\circ} \mathrm{C}$ and decreased very slowly when the semen had been cooled to nearly $0^{\circ} \mathrm{C}$ (Fig. 3). Three of 4 incubated samples gave negative aldose test within 10 minutes. In one test the aldose score declined gradually and became negative after 50 minutes (Fig. 1). On the other hand, samples cooled to nearly $0^{\circ} \mathrm{C}$ maintained positive aldose test for 1 to 4 days or more. The vas-deferens semen diluted with the nodified RingerLocke solution showed a similar pattern as far as the decrease of aldose score was concerned. The test became negative within 10,20 , and 30 minutes when samples were incubated at $30^{\circ} \mathrm{C}$. A positive score test was maintained for 1 to 2 days when the sample was cooled to nearly $0^{\circ} \mathrm{C}$ (Fig. 3). These changing patterns of aldose test are almost identical with those of rather dense ejaculated semen. They show that the motile spermatozoa of cock utilize the aldose, presumably blood glucose, contained in the transparent fluid. 


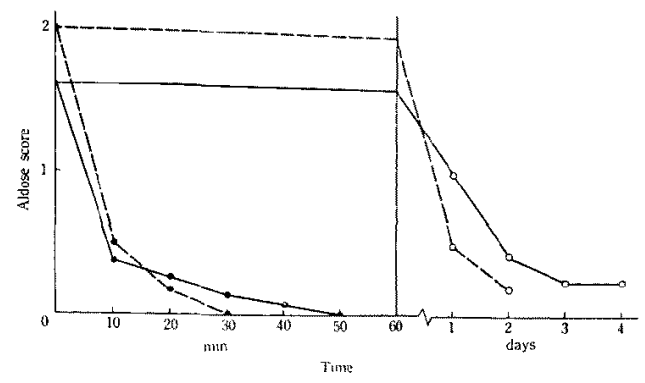

Fig. 3. Utilization of aldose contained in the trans. parent fluid and modified Ringer-Locke solution.

The vas deferens semen diluted with the transparent fluid at the rate of $1: 1$.

….. The vas deferens semen diluted with modified Ringer-Locke solution at the rate of $1: 1$.

incubated at $30^{\circ} \mathrm{C} ; \mathrm{O}$ cooled at $0^{\circ} \mathrm{C}$.

When the vas-deferens semen was diluted with the modified Ringer-Locke solution at the rates of $1: 1,1: 2$, and $1: 5$, the aldose scores of the dilutions were 2,2 plus, and almost 3 , respectively. When these diluted semen samples were incubated at $30^{\circ} \mathrm{C}$, the aldose score declined gradually and became zero within 20 and 60 minutes of incubation in the first 2 samples, respectively. The score of the third sample only declined to 2 after 80 minutes of incubation and did not change for the next 140 minutes. The next morning, i.e., 19 hours later, the spermatozoa were dead and micro-organisms were found in the semen, but the aldose test was still positive, showing a score of 1 . These diluted semen samples can be compared with the ejaculates in different densities.

From these results, it seems that cock spermatozoa utilize the aldose contained in the ejaculated semen and that the rate of exhaustion of aldose depends upon both the concentration and motility of the spermatozoa. In the ejaculated semen of high sperm density which is probably composed of a large amount of vas-deferens semen and a small amount of transparent fluid, there are many spermatozoa and a little glucose and rapid loss of aldose occurs. On the contrary, in the semen of lower sperm density, the aldose is presumably preserved for a longer period due to the larger amount of aldose and the smaller number of spermatozoa utilizing aldose.

The fact that the aldose in the ejaculate of the cock was utilized by spermatozoa suggests that glycolysis took place continuously until practically all the glucose was used up in the semen. Wilcox ${ }^{3)}$ reported a marked reduction in $\mathrm{pH}$ of cock's semen within one hour after collection. He also stated that the $\mathrm{pH}$ of the semen stored at low temperature $\left(10^{\circ} \mathrm{C}\right)$ decreased gradually. This tendency agreed with the results of this experiment that the aldose (glucose) was utilized by active spermatozoa and that most of it was consumed within 30 minutes. On the contrary, Scminder et al. ${ }^{4}$ reported that cock's semen lacked, almost completely, glycolytic processes owing to the absence of reducing carbohydrate. In their experiment, however, semen was collected into a container warmed beforehand in a water bath at $41^{\circ} \mathrm{C}$ and brought to the laboratory, where determinations of total reducing substance and fructose were carried out after the semen had been cooled for 30 minutes to $10^{\circ} \mathrm{C}$. Hence, it is possible 


\title{
Utilization of aldose by sperm
}

that the glucose contained in the semen samples was used up before the determination, since, as described before, most of the glucose in the semen can be used up within 30 minutes after collection, even at a temperature from $10^{\circ}$ to $20^{\circ} \mathrm{C}$ (Fig. 2).

\section{Summary}

1. When cock's semen was allowed to stand at room temperature from $10^{\circ}$ to $20^{\circ} \mathrm{C}$, the aldose, presumably blood glucose, contained in the ejaculate was utilized by spermatozoa. Most of the aldose could be used up within 30 minutes after collection.

2. Cock spermatozoa utilized the aldose contained in the transparent fluid and the glucose in the modified Ringer-Locke solution.

3. The rate of exhaustion of the aldose depended upon both the concentration and motility of spermatozoa.

\section{References}

1) Nishiyama, H. J. Fac. Agric,, Kyushu Univ., 10: 277, 1955.

2) and T. Fujishima. Mem. Fac. Agric. Kagoshima Univ. 4:27, 1961.

3) WlLcox, F.H. Poult. Sci., 37: 444, 1958.

4) Schindeler, H., R. Volcani and Sh. Weinstein ibid., 37: 21, 1958.

\section{鶏精子による aldose の利用について}

\author{
西山久吉・藤島通 \\ （鹿览島大学㸃学部畜虐学教室）
}

綿の射出精漼や透明液（副生殖器官排出液）中に含ま

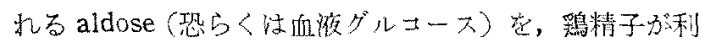

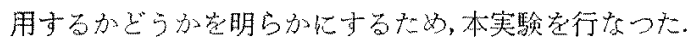

(1) 鼣の射出精液老 $10 \sim 20^{\circ} \mathrm{C}$ の空内に放置子机ば, その中に含东れる aldose は，精子によつて利用さ机， 30 分以内に大の大部分が消鿓された。
（2）鶏精子は，透明液中の aldose や， modified Ringer-Locke 源中のグルコース空利用した。

(3) Aldose 消費の速さ怔，精子の湴度已運動力の強 さによつて異なり， $0^{\circ} \mathrm{C}$ 付近の低温に保持したとき，そ

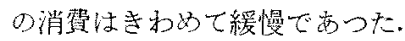

